\title{
EVALUATION OF HAPPINESS IN ALBANIAN EDUCATION, LEGISLATION AND POLICIES
}

In Happiness And Contemporary Society : Conference Proceedings Volume (Lviv, March, 20-21, 2021). Lviv: SPOLOM, 2021. P. 194-198. https://doi.org/10.31108/7.2021.44

ISBN 978-966-919-697-2 


\author{
MIÇO Heliona \\ PhD, Lecturer, Department of Law, Epoka University (Tirana, Albania)
}

\author{
KODRA Klara \\ Msc., Researcher \\ Centre for European Development and Integration (Tirana, Albania)
}

\title{
EVALUATION OF HAPPINESS IN ALBANIAN EDUCATION, LEGISLATION AND POLICIES
}

Studies show that happiness positively affects the student's learning process. Happy students have higher academic achievements, better relationships with friends as well as more active participation in secondary activities in education. International education policies estimate that happiness is correlated with well-being and life quality. Yet, happiness is not considered as one of the mail goals in the Albanian education policy and legislation. The article will firstly shed light on the impact of happiness on better student performance. It will reflect the international legislation and policies which have valued happiness as a fundamental human goal, by extending the relevant analysis in the field of legislation and policies in Albania. The analyses will help to understand the place that happiness occupies in the goals of education and the need for evaluation of the level of student happiness as a tool towards student well-being and education quality. The article will focus on the need to include the concept of happiness in the whole educational process, in order to positively encourage students not only in terms of higher school performance but also in terms of their overall well-being.

Key words: education, happiness, Albania, students, well-being

\section{Introduction}

It is excepted as a non well-studied problem amongs educational systems the presence of happy schools (Talebzadeh et al., 2011). Indifferent presence of students in classroom and school premises, lack of enthusiasm and their non-participation in the learning process indicate detached feelings for education. Nonetheless, policymakers, administrators, teachers and parents want children to be happy.

Different studies from elementary to high school have indicated the correlation of happiness with motivation and academic achievement (Cagle, 2017). It was found (Fritz, as cited in Tabbodi, 2015) that happiness is one of tha variables that are related to academic achievment. This finding is supported by Datu, 2017 according to whom happy individuals are likely to have high levels of academic engagement. Research finding have shown that people who have a high sense of happiness are more active in avademic performace and progress of higher education.

In addition to the impact on school achievments, happiness is accepted to affect quality of life. PISA 2015 Results emphasise that good educators strive to improve children's life prospects but also care about the quality of their students' current life. At the same time, UNESCO study (2017) found that a growing body of research has highlighted the crucial relationship between happiness and educational quality, whereby 
schools that prioritize learner wellbeing have the potential to be more effective, with better learning outcomes and greater achievements in learners' lives. While according to Noddings (2003), happiness and education are, properly, intimately connected. Happiness should be an aim of education, and a good education should contribute significantly to personal and collective happiness.

\section{Reflection of happiness in international instruments and policies}

According to the resolution 65/309 of the United Nations General Assembly, the pursuit of happiness is a fundamental human goal. Starting from the importance it occupies, happiness is reflected in the global policy agenda from July 2011 and it is being considered as one of the fundamental human rights.

For more, the United Nations Educational, Scientific and Cultural Organization (UNESCO) believes that social inclusion, equity, work and education are especially important for human well-being and happiness. Quality education for all is an essential prerequisite to providing people with the skills and knowledge needed to access decent jobs and empower them to shape their own futures (UN, (2012), Happiness: towards a holistic approach to development Draft note). The quality education is one of the UNESCO and Sustainable Development Goals. In the context of quality education, the learner understands education as a public good, a global common good, a fundamental human right and a basis for guaranteeing the realization of other rights (UNESCO, (2017), Education for sustainable development goals. Learning objectives).

The first ever report on happy schools and learner well-being in the Asia-Pacific region was launched by UNESCO Bangkok, in 2016. It embraces a diversity of talents and intelligence by recognizing the values, strengths and competencies that contribute to enhancing happiness, then traditional way of teaching and learning. Suggested criteria for achieving these goals include supporting positive teacher attitudes and attributes, encouraging learner freedom, creativity and engagement, and creating a warm and friendly learning environment. (UNESCO Office Bangkok and Regional Bureau for Education in Asia and the Pacific, (2016), Happy schools! A framework for learner wellbeing in the Asia-Pacific).

The Council of Europe has paid special attention to well-being in school. According to the Council of Europe, since well-being has many facets, improving students' well-being in schools requires a whole-school approach, by involving both teachers and parents. Thereof, the crucial role of schools at supporting students to make healthy lifestyle, choices and understand the effects of their choices on their health and well-being, is closely related to well-being. (Council of Europe campaign, Improving well-being at school ).

The evaluation of children's happiness in school was made for the first time by the PISA study 2012. According to this study, the subjective evaluations of social environment for 15 -year-olds provide a good indication of whether education systems are able to foster or hinder overall student well-being. On average, students report feeling happy at school: across OECD countries $80 \%$ of students agree or strongly agree with the statement "I feel happy at school". The proportion of students who report being happy at school is highest in Indonesia, Albania and Peru and is lowest in Korea, the Czech Republic and the Slovak Republic. (OECD, 2013, PISA 2012 Results: Ready to learn. Students' engagement, drive and self-beliefs, p. 33). 
While, the World Happiness Report 2020 (World Happiness Report, 2020, p. 9) evaluates Nordic countries as constantly among the happiest in the world connecting this with higher personal and institutional trust as key factors in explaining why life evaluations are so high in those countries. The study demonstrates that the quality of the government and public institutions matters for life satisfaction. From this point of view, even schools as public institutions play a crucial role to personal happiness of pupils and further to public at large. Albania is ranked $105^{\text {th }}$, based to the $2020^{\text {th }}$ World Happiness Report (World Happiness Report, 2020, p. 181).

The Albanian education legislation and policies regarding happiness

Albania comes from a communist past where the need for massification of education by the state minimized the happiness of students in the teaching process and at school. The happiness at school does not depend on compulsory education or state policies to increase school attendance. The Albanian reality of the communist period has shown that the state itself was the first violator of the individual's right to be educated freely, emphasizing the planning process in the realization of education rather than the desire of students to attend the school they wanted or which they were inclined for (Kambo, 2005, Arsimi në Shqipëri 1945-1960, p 138).

Even after 30 years of transition, the concept of happiness in the legal framework of education is not widely addressed. One of the goals of the pre-university education system in Albania expressed in the respective legislation is to create the conditions and opportunities for students to contribute to the construction of individual and societal well-being and to face the challenges of life in a constructive way (On Pre-university Education System in the Republic of Albania Law of 2012).

While the Strategy of pre-university education designed by the Ministry of Education and Sports is focused on evaluating the results of students as the main indicator of quality and performance of the education system, curricula and learning process, textbooks, infrastructure and inclusion, avoiding the analysis of well-being in education (MoES, 2014-2020, p 18).

Despite the lack of inclusion in the legal framework of happiness as one of the main human rights in Albania and as one of the main goals of education, it is sporadically requested to assess the satisfaction of the educational service by students and parents. The satisfaction of the educational service made by parents has served to measure the work done by the school principal til 2020 (On the procedures of appointment and dismissal of the director of the public institution of pre-university education, Instruction of the Ministry of Education and Science, 2013). While the opinion of students serves to express their attitude towards the quality of school services (School Performace Card, 2014).

Admitting the growing importance given to evaluation of the satisfaction of students, parents and teachers from the services provided by school and from the relationships established between the parties, (On the approval of the school quality evaluation package, Order of the Minister of Education, Sport and Youth, 2020), this is not related to the evaluation of students' happiness in school. According to Unesco (2014), school happiness is based on relationships, including empathy, tolerance, respect for diversity, communication and teamwork. These components are not evaluated and even less involved in legal directives or educational policies. 
As a result, it is necessary to understand to what extent the child is feeling happy in school environment, and what are the factors that influence in this direction, in order to build up the legal framework in support of this goal.

\section{Conclusions}

The Albanian legislation in the field of education has intervened in pre-service training in education in order to specify the content of the respective study programs (Miço, 2019). Given the fact that the content of study programs in the field of teaching is standardized through legislative intervention, we find this intervention necessary in the inclusion of happiness and well-being, as the axis of the learning process and education of students.

Based on the research and studies on the impact of happiness in education, we find the connection between students' happiness in school and their performance in education. Research has identified a direct link between happy schools on one side and student well-being on the other.

Consequently, it is necessary to include happiness as one of the goals of education in Albania and to extend the impact evaluation of happiness in Albanian policies and educational legislation. Given the international instruments, the Albanian educational policies should to be addressed in this direction in order to create conditions for acceptable right to education.

\section{REFERENCES}

1. Cagle, J. (2017). "A study of the life satisfaction of students and its effect on their academic achievement" (Doctoral Dissertation). Available from

2. https://www.cn.edu/libraries/tiny_mce/tiny_mce/plugins/filemanager/files/Dissertati ons/Dissertations2017/John_B_Cagle.pdf.

3. Council of Europe. Improving well-being at school. Retrieved on 22 February 2021 from https://www.coe.int/en/web/campaign-free-to-speak-safe-to-learn/improvingwell-being-at-school.

4. Datu, J., King, R., \& Valdez, J. (2017). The academic rewards of socially-oriented happiness: Interdependent happiness promotes academic engagement. Journal of School Psychology, 61, 19-31.

5. Kambo. E, (2005). Arsimi në Shqipëri 1945-1960. Albanian Academy of Sciences, Institute of History. "Mësonjëtorja" Printing House, Tiranë 2005. p. 138.

6. Miço, H. (2019). "The Teaching Profession in Albania and the Continuous Need for Improvement through Teacher Training Reforms". Rethinking Teacher Education for the 21st Century Trends, Challenges and New Directions. Verlag Barbara Budrich $\mathrm{GmbH}$ p. 156

7. Noddings, N. (2003). Happiness and Education. Stanford University. California. September 2003.

8. OECD. (2017). PISA 2015 Results (Volume III): Students' well-being. p. 70.

9. OECD. (2013). "PISA 2012 Results: Ready to learn. Students' engagement, drive and self-beliefs" - Volume III 2013, p. 33. DOI: https://dx.doi.org/10.1787/9789264201170-en. Retrieved on 20 February 2021 from https://read.oecd-ilibrary.org/education/pisa-2012-results-ready-to-learn-volumeiii 9789264201170 -en\#page4.

10. On the Pre-university Education System in the Republic of Albania Law of 2012,
No.
69
of
21.6.2012,
Retrieved
from 
http://www.arsimi.gov.al/al/newsroom/ligje/ligj-nr-69-2012-per-sistemin-arsimorparauniversitar-ne-republiken-e-shqiperise \&page $=1$.

11. On the Adoption of the Strategy for the Development of Pre-University Education, for the Period 2014-2020, Decision of the Council of Ministers, 2016, No. 11, dated 11.01.2016, Retrieved from Official Bulletin No. 2, dated 19 January 2016.

12. On the procedures of appointment and dismissal of the director of the public institution of pre-university education, Instruction of the Ministry of Education and Science, No. 57, dated 12.11.2013. Retrieved from https://arsimi.gov.al/udhezim-nr57-date-12-11-2013-per-procedurat-e-emerimit-dhe-shkarkimit-te-drejtorit-teinstitucionit-publik-te-arsimit-parauniversitar/

13. On the approval of the school quality evaluation package, Order of the Minister of Education, Sport and Youth, No. 268, dated 28.08.2020. Retrieved from https://www.ascap.edu.al/wp-content/uploads/2020/08/7-Mars-2020-Metodologjia-eVleresimit-te-brendshem-1-1-1.pdf

14. Tabbodi, M. et al. (2015). "The relation between happiness and academic achievements". European Online Journal of Natural and Social Sciences 2015. Vol. 4, No. 1. Special Issue on New Dimensions in Economics, Accounting and Management. ISSN 1805-3602.

15. Talebzadeh, F. Samkan, M. (2011). "Happiness for our kids in schools: A conceptual model". Procedia - Social and Behaviour Sciences. No. 29, (2011). (p.1462-1471). Elsevier Ltd.

16. UNESCO. (2014). Learning to live together. Education policies and realities in the Asia-Pacific. Retrieved from https://bangkok.unesco.org/content/learning-livetogether-policies-and-realities-asia-pacific

17. UNESCO. (2017). Asia-Pacific Education Thematic Brief. "Promoting learner happiness and well-being" pg.1. May 2017. Retrieved on 20 February 2021 from https://unesdoc.unesco.org/ark:/48223/pf0000248948 p. 1.

18. United Nations General Assembly. (2011). Res/65/309. "Happiness: towards a holistic approach to development". Retrieved on 19 February 2021 from

19. https://documents-ddsny.un.org/doc/UNDOC/GEN/N11/420/70/PDF/N1142070.pdf?OpenElement.

20. United Nations. (2012). Happiness: towards a holistic approach to development Draft note 6 November 2012 Retrieved on 19 February 2021 from https://www.un.org/esa/socdev/ageing/documents/NOTEONHAPPINESSFINALCL EAN.pdf.

21. UNESCO. (2017). "Moving forward the 2030 Agenda for Sustainable Development". Retrieved from https://en.unesco.org/sustainabledevelopmentgoals.

22. UNESCO. (2017). "Education for sustainable development goals. Learning objectives". p. 23. Retrieved on 21.02.2021 from https://unesdoc.unesco.org/ark:/48223/pf0000247444.

23. UNESCO Office Bangkok and Regional Bureau for Education in Asia and the Pacific. (2016). "Happy schools! A framework for learner well-being in the AsiaPacific”. ISBN 978-92-9223-541-3 (print), 978-92-9223-542-0 (electronic). $\begin{array}{lllll}\text { Retrieved on } & 20 & \text { February } & 2021 & \text { from }\end{array}$ https://unesdoc.unesco.org/ark:/48223/pf0000244140.

24. World Happiness Report 2020. p. 9. Retrieved on 20 February 2021 from https://happiness-report.s3.amazonaws.com/2020/WHR20.pdfm. 